\title{
Predictive and diagnostic value of VZV infections in HIV patients: Clinical and laboratory cross-correlations between VZV and HIV infections
}

\author{
Verra Prokopia ${ }^{1}$, Paparizos $V^{1}$, Nikolaidou Ilektra ${ }^{1}$, Antoniou Christina ${ }^{1}$, Katsambas $A^{1}$ and Rigopoulos $D^{2}$ \\ ${ }^{1}$ EKPA University of Athens, Medical School, $1^{\text {st }}$ Department of Dermatology, “A.SYGROS” Hospital, Athens, Greece \\ ${ }^{2}$ EKPA University of Athens, Medical school, $2^{\text {nd }}$ Department of Dermatology, University Hospital “ATTIKON”, Athens, Greece
}

\begin{abstract}
Background: People with healthy immune system can be exposed to certain viruses, bacteria, or parasites and have no reaction to them-but people living with HIV/AIDS can face serious health threats from what are known as "opportunistic" infections (OIs), including VZV , HSV and CMV. These infections are called "opportunistic" because they take advantage of their weakened immune system, and they can cause devastating illnesses. It is possible that we may have underestimated the association of opportunistic infections with subsequent VL elevation and CD4+T cell count decline. However, we already know that there is an association between people having had an opportunistic illness and short- and long-term effects on HIV RNA VL and CD4+ cell count.
\end{abstract}

Objectives: To assess the predictive and diagnostic value of VZV infections in HIV patients, the clinical and laboratory cross-correlations between VZV and HIV infections.

Patients/Methods: Two thousand one hundred eighteen (2118) HIV- positive patients were included in this study. These patients were hospitalized in a Specialized Infectious Disease Unit of “A. Sygros" Hospital from 1/1/1988 up to 31/12/2010 (over 23 years). They were classified based on demographic data (age, gender and source of infection) and characteristics of the VZV infection (history of the HZ infection, clinical picture of VZV after the diagnosis of HIV infection and recurrence rates). All these findings were correlated with CD4+ cell count and HIV RNA VL.

Results: Out of the 2118 HIV-positive patients, 317 patients (15\%) presented with VZV (varicella or Herpes Zoster). The overall patients follow-up was 23 years (1.007, 33 person/years). Twenty-eight (28) patients of the $317(8,8 \%)$, had VZV history prior to HIV diagnosis. In 32 patients ( 10\%), relapses of VZV were referred. The primary attack of VZV and its relapses were associated with low levels of CD4+ cells $(<100)$. However, the difference in counts of CD4+ between HZ first attack and its relapses was statistically borderline non-significant $(\mathrm{p}=0.051)$.

Conclusions: The VZV infection is associated mainly with progressed immuno-suppression. (Infection lowers CD4 count and the lower CD4 count means a weaker immune system.) This important finding shows the opportunistic character of VZV infections. Different opportunistic infections are associated, at their onset, with significantly different HIV RNA levels, regardless of CD4 count and ART.

\section{Introduction}

More than $95 \%$ of adults (aged $>20$ years) born in the United States have immunity to varicella, the vast majority due to primary VZV infection. Reactivation of latent VZV results in herpes zoster (or shingles). A person's lifetime risk for herpes zoster is $15 \%$ to $20 \%$, with the highest incidence occurring in the elderly and immunocompromised individuals, like people taking immunosuppressive drugs, chemotherapy due to malignancy or having HIV. The incidence of herpes zoster is $>15$-fold higher for HIV-infected adults than for agematched controls. Herpes zoster can occur in HIV-infected adults at any CD4 T lymphocyte (CD4) cell count, but frequency of disease is highest with CD4 counts of $<200$ cells $/ \mu \mathrm{L}$. Antiretroviral therapy (ART) has not been shown to reduce the incidence of herpes zoster in adult populations: in fact, rates appear to be higher in the period immediately after initiation of ART. Most herpes zoster-related complications in HIV-seropositive patients, including disseminated herpes zoster, recurrent, necrotic, hemorrhagic, bullous and systemic involvement, occur in patients with CD4 counts of $<200$ cells $/ \mu \mathrm{L}$. The CNS is the primary target organ for herpes zoster dissemination in patients co- infected with HIV. Various VZV-related neurologic syndromes occur in HIV-infected patients, including CNS vasculitis, multifocal leukoencephalitis, ventriculitis, myelitis and myeloradiculitis, optic neuritis, cranial nerve palsies and focal brain-stem lesions, and aseptic meningitis.

\section{Sample and methods}

The sample of our study, included HIV positive patients of the Specialized Infectious Disease Unit of "A. Sygros" Hospital, from 01/01/88 to $31 / 12 / 2010$ (23 years). We have recorded 2118 seropositive individuals, of whom 317 developed VZV infection which manifested

Correspondence to: Prokopia Verra, Dermatologist - Venereologist, Clinical assistant in "A. Sygros " Hospital, L. Galatsiou 74 - Psichari 47, Galatsi, Athens, Greece, P.C. 11141; Tel: + 306979491117; E-mail: prverra@yahoo.gr

Key words: CD4+ T cell lymphocyte count, HIV RNA viral load, HIV, opportunistic infections, $V Z V$

Received: June 21, 2016; Accepted: July 14, 2016; Published: July 18, 2016 
as either Herpes Zoster (HZ), mainly, or varicella. We have studied the possible VZV history, the time of VZV appearance after diagnosis of HIV infection, the VZV forms (e.g. disseminated HZ, recurrent HZ, $\mathrm{HZ}$ encephalomyelitis, unilateral $\mathrm{HZ}$ involving multiple dermatomes), the CD4+ count and the HIV- RNA load, at the first attack of HZ and its relapse.

In similar studies, VZV infection in HIV positive patients is associated with underlying immunodeficiency. If you're beginning HIV testing or treatment, you'll learn to keep a sharp eye on your viral load and CD4 count. These two counts speak volumes about your HIV and immune system health. They alert the immune system to invading viruses (like VZV HSV, CMV) and bacteria. They provide important information on virus progression, therapy response, and help determine whether to begin HIV treatment.

\section{Results}

We have recorded 2118 HIV-positive patients that were hospitalized in a Specialized Infectious Disease Unit of “A. Sygros" Hospital from $1 / 1 / 1988$ up to $31 / 12 / 2010$ (over 23 years).

$317(15 \%)$ developed VZV infection after diagnosing HIV.28 patients (8.8\%) had VZV history. 32 patients (10.1\%) developed VZV relapses and in 10 patients (3.15\%), extensive VZV and persistent Herpes Zoster entered the diagnosis of HIV. In all these patients (317), the median time to onset of VZV was 3.26 years (Figure 1).

Out of the 317 with VZV, $275(86,7 \%)$ were men, and $42(13,3 \%)$ women. $(\mathrm{p}=0,99)$
272 were homosexuals or bisexuals $(85.5 \%)$ and 45 heterosexuals (14.2\%).

The mean age was $38.05+/-10.53$ and the follow-up time for these patients ranged from 1-276 months.

98 of 317 HIV-positive people with VZV (31\%) developed coinfection with HSV and CMV. 83 patients (84.7\%) developed coinfection VZV with HSV and 11 patients (11.22\%) co-infection VZV with CMV. 4 patients $(4,08 \%)$ had all the 3 infections at the same period of time (Figure 2).

At the first attack of HZ, the average count of CD4+ lymphocytes was quite low ( $344.0+/-254.0)$, fluctuating widely between $1 \mathrm{cell} / \mathrm{ml}$ to $1412 \mathrm{cell} / \mathrm{ml}$. The median count was 297.5 . This fact proves that $\mathrm{HZ}$ is associated with serious immunodeficiency.

At the $\mathrm{HZ}$ relapses (32 individuals-10.1\%), the average count of CD4+ was $253+/-178,8$ cell / ml. The median count was 205, 0 cell/ $\mathrm{ml}$. However, the difference in counts of CD4+ between HZ first attack and its relapse was statistically borderline non-significant $(\mathrm{p}=0.051)$, although the $\mathrm{CD} 4+$ count continued to decline in the following $\mathrm{HZ}$ relapses.

At the first HZ episode, the average value of HIV RNA VL was 136 $200+/-519400$, fluctuating widely between $<20$ to 6.000 .000 copies $/ \mathrm{ml}$. The median value was 19.200 .

At $\mathrm{HZ}$ relapse (32 individuals $-10.1 \%$ ), the average value of HIV RNA VL was $57.390+/-97.700$, fluctuating again widely between $<20$

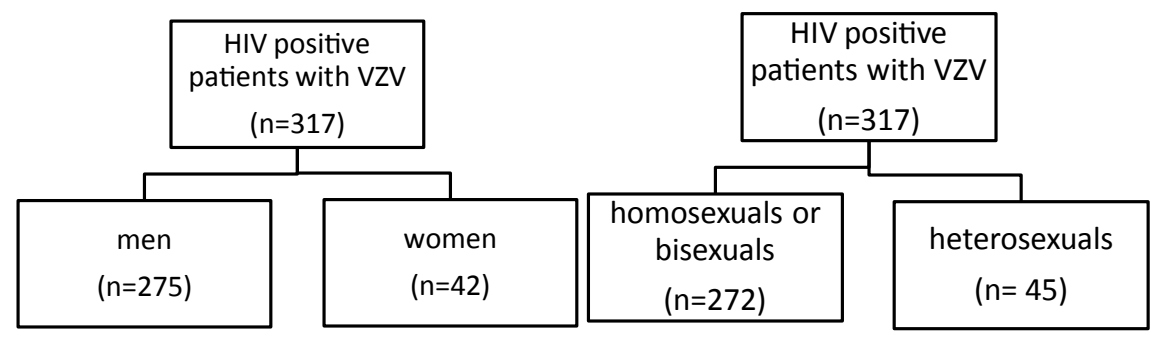

Figure 1. Classification of HIV Positive patients.

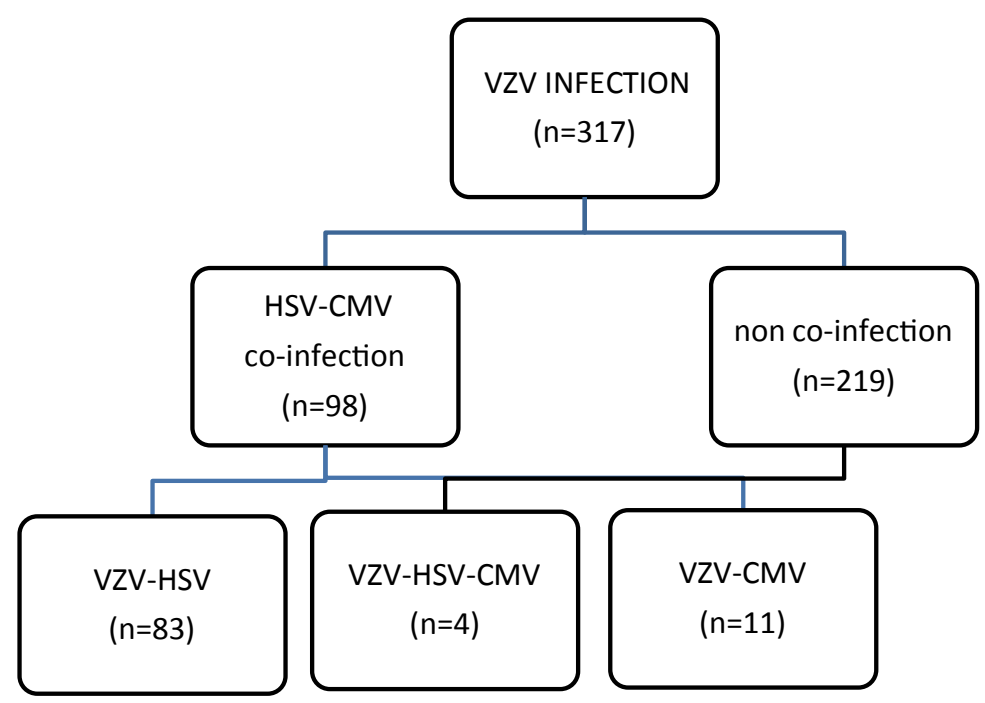

Figure 2. HIV and Co-infections. 
to 350,000 copies $/ \mathrm{ml}$. The median value was 5.300 .

\section{Discussion}

Herpes zoster $(\mathrm{HZ})$ is due to reactivation of latent varicella zoster virus (VZV), and can be a debilitating illness. Varicella-zoster virus (VZV), a neurotropic herpesvirus, is the causative agent of both varicella (chickenpox) and zoster (shingles). As with the other herpesviruses, VZV causes both acute illness and lifelong latency. Varicella usually is a benign and self-limiting illness, but can be more severe in elderly and in immunocompromised individuals, likely owing to impaired cell-mediated immunity. These individuals are at much higher risk of pneumonia and disseminated disease with visceral involvement. The incidence of $\mathrm{HZ}$ in the general population is around $0.15-0.33 / 100$ person years with a higher incidence $(0.5-0.9 /$ personyears) in individuals aged $50-80$ years.

HIV binds to CD4 receptors on helper T-lymphocytes, monocytes, macrophages and neural cells. CD4 cells migrate to the lymphoid tissue where the virus replicates and then infects new CD4-positive cells. As the infection progresses, depletion or impaired function of CD4 cells predisposes to the development of immune dysfunction. The success of antiretroviral therapy (ART, formerly highly active retroviral therapy, or HAART) has revolutionized the way we think about HIV infection. Far fewer patients now progress to AIDS, which - due to the stigma surrounding the diagnosis - is increasingly being known as late-stage HIV disease. The number of circulating viruses (viral load) predicts progression to late-stage HIV disease.

Scientific studies show that in immunocompetent individuals, the first event of Herpes Zoster alerts the cell-mediated immunity, preventing in this way from following relapses of the infection. However, in HIV-positive patients and in people with other immunodeficiency (like SLE, etc.), it has been observed increased incidence of $\mathrm{HZ}$, disseminated HZ, recurrent HZ, HZ encephalomyelitis, unilateral HZ involving multiple dermatomes . According to a study of Kebo et al., in 282 episodes with HZ, 5\% relapsed in the first six months and $10 \%$ during the $1^{\text {st }}$ year, while the corresponding rate is $1 \%$ and $4 \%$ in the general population. Incidence of $\mathrm{HZ}$ increases with age, along with certain conditions that impair cell-mediated immunity.

In our study, we examined 2118 people for a period of 23 years (one of the largest in overtime study) and we found 317 patients (15\%) that presented VZV infection after the diagnosis of HIV. 28 patients $(8,8 \%)$ had HZ history. In 10 patients $(3,15 \%)$ the HIV diagnosis was entered due to extensive or persistent HZ. After HIV diagnosis, the mean time of onset of $\mathrm{HZ}$ was 3, 26 years and the median age of patients was 38, $05+/-10,53$ years.

Patients who have risk behaviors of HIV infection should receive regular surveillance for undiagnosed HIV infection when they present with herpes zoster. According to a study of Lai SW, Lin CL, Liao KF, Chen WC, that was published in J Formosa Med Assoc. 2016 May, they reached the same conclusion. Some studies have revealed that herpes zoster in areas with high prevalence of HIV infection has an approximately $90 \%$ positive predictive value for underlying HIV infection.

Of the 317 seropositive patients with VZV, $275(86,7 \%)$ were men, and $42(13,3 \%)$ women. $(\mathrm{p}=0,99)$, whereas 272 were homosexuals or bisexuals ( $85.5 \%)$ and 45 heterosexuals (14.2\%). Their median age was $38.05+/-10.53$. The follow-up time for these patients ranged between $1-276$ months (1.007,33 person-years).
98 of 317 HIV-positive people with VZV (31\%) developed coinfection with HSV and CMV. 83 patients out of 98 (84.7\%) developed co-infection VZV with HSV and 11 patients (11.22\%) co-infection VZV with CMV. 4 patients (4.08\%) had all the 3 infections at the same period of time.

CD4 cells, also called T-cells, are like the alarm bells of the immune system. They alert the immune system to invading viruses and bacteria. Certain receptors on the $\mathrm{CD} 4$ cell make them a prime target for HIV infection. Interactions between the viral envelope glycoprotein gp120 and the cell surface receptor CD4 are responsible for the entry of human immunodeficiency virus type 1 (HIV-1) into host cells in the vast majority of cases. HIV-1 replication is commonly followed by the disappearance or receptor down modulation of cell surface CD4. This potentially renders cells non susceptible to subsequent infection by HIV-1, as well as by other viruses that use CD4 as a portal of entry. Disappearance of CD4 from the cell surface is mediated by several different viral proteins that act at various stages through the course of the viral life cycle, and it occurs in T-cell lines, peripheral blood CD4+ lymphocytes, and monocytes of both primary and cell line origin. At the cell surface, gp120 itself and in the form of antigen-antibody complexes can trigger cellular pathways leading to CD4 internalization. Intracellularly, the mechanisms leading to CD4 down modulation by HIV-1 are multiple and complex; these include degradation of CD4 by $\mathrm{Vpu}$, formation of intracellular complexes between CD4 and the envelope precursor gp160, and internalization by the Nef protein. Each of the above doubtless contributes to the ultimate depletion of cell surface $\mathrm{CD} 4$, although the relative contribution of each mechanism and the manner in which they interact remain to be definitively established. Infection lowers CD4 count. Lower CD4 count means a weaker immune system.

A normal CD4 count ranges from 500-1,000 cells $/ \mathrm{mm}^{3}$. According to AIDS.gov, a count of fewer than $200 \mathrm{cells} / \mathrm{mm}^{3}$ is one of the qualifications for an AIDS diagnosis.

In our study, at the first $\mathrm{HZ}$ attack, the mean level of CD4 lymphocytes was quite low $(344.0+/$ - 254.0) with mean value 297.5 , fluctuating widely between $1 \mathrm{cell} / \mathrm{ml}$ to $1412 \mathrm{cell} / \mathrm{ml}$. This fact proves that Herpes Zoster episodes are associated with serious immunodeficiency. When HZ relapsed, in 32 individuals (10.1\%), the mean CD4+ count was $253+/-178,8 \mathrm{cell} / \mathrm{ml}$. The median value was $205,0 \mathrm{cell} / \mathrm{ml}$. The CD4+ count between first appearance of VZV and its relapse was statistically marginally non-significant. $(\mathrm{p}=0.051)$. However, the CD4+ count continued to decline in the following $\mathrm{HZ}$ relapses. $(\mathrm{CD} 4<100)$

In similar studies, it was found that all opportunistic infections (varicella, HZ, relapses) were associated with a gradual decline of CD4+ cells. In a Margolick study, in 859 patients, after 18 months of

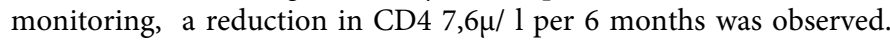
Low circulating CD4+ cell numbers and CD4 cell dysfunction are distinguishing features of HIV-mediated disease.

Viral load is the best gauge of the level of HIV in the body. It is measured as the number of copies of HIV-1 per milliliter of blood plasma (copies $/ \mathrm{mL}$ ). According to the U.S. Department of Health and Human Services (HRSA), the lowest levels of detectable viral load are about $40-75$ copies $/ \mathrm{mL}$. The highest measure can be over 500,000 copies/mL.

Low viral load means lower amounts of HIV activity. The goal of HIV therapy is to lower the viral load to levels below 40-75 copies $/ \mathrm{ml}$. It's important to know that just because viral load may fall below these 


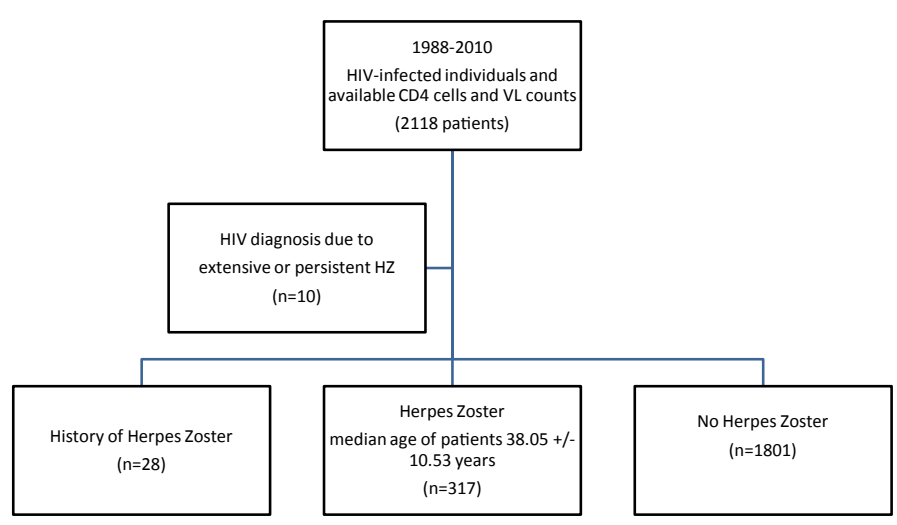

Figure 3. VZV infection after the diagnosis of HIV.

\section{Typical Course of HIV Infection}

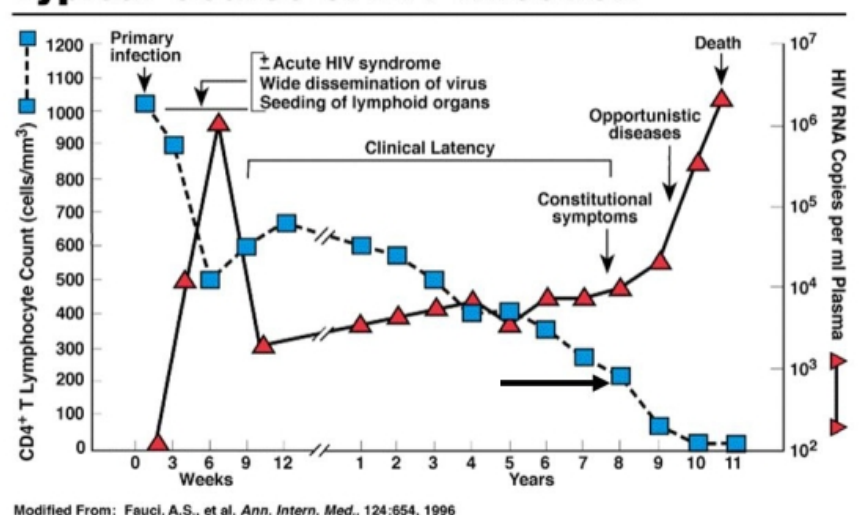

Figure 4. Typical course of HIV infection.

levels, does not mean HIV is gone from the body.

In our study, at the first $\mathrm{HZ}$ attack the mean value of HIV RNA VL was $136200+/-519400$ copies $/ \mathrm{ml}$, fluctuating widely between $<20$ to $6,000,000$ copies $/ \mathrm{ml}$. The mean value was 19,200. When HZ relapsed, in 32 individuals (10.1\%), the mean value of HIV RNA VL was 57.390 +/- 97.700 copies/ml, fluctuating between $<20$ up to 350,000 copies/ $\mathrm{ml}$. The median level of HIV RNA VL was 5.300 copies/ml (Figure 4).

The viral load $(\mathrm{VL})$ is an independent risk factor for development of opportunistic infections. The data of several studies show a statistically significant correlation between different opportunistic infections and the HIV-RNA levels. This correlation was independent of CD4cell counts and the type of ART (therapy) [1-68].

According to our study, we should associate and adjust the antiviral therapy mainly according to the CD4 levels and not the Viral Load. CD4 count, the measure of immune system health, is the major factor in deciding whether to begin HIV therapy. Treatment guidelines recommend that therapy should begin when CD 4 counts fall below 350 cells $/ \mathrm{mm}^{3}$. Treatment may also be considered for patients with CD4 counts up to 500 cells $/ \mathrm{mm}^{3}$ if they have a high viral load, or if they are experiencing a rapid drop in CD4 cell count.

\section{References}

1. Thomas SL, Hall AJ (2004) What does epidemiology tell us about risk factors for herpes zoster? Lancet Infect Dis 4: 26-33. [Crossref]

2. Johnson R, McElhaney J, Pedalino B, Levin M (2007) Prevention of herpes zoster and its painful and debilitating complications. Int J Infect Dis 11 Suppl 2: S43-48. [Crossref]

3. Song JY, Lee JS, Jung HW, Choi HJ, Lee JS, et al. (2010) Herpes zoster among HIVinfected patients in the highly active antiretroviral therapy era: Korean HIV cohort study. J Acquir Immune Defic Syndr 53: 417-418. [Crossref]

4. Blank LJ, Polydefkis MJ, Moore RD, Gebo KA (2012) Herpes zoster among persons living with HIV in the current antiretroviral therapy era. J Acquir Immune Defic Syndr 61: 203-207. [Crossref]

5. Lai SW, Lin CL, Liao KF, Chen WC (2016) Herpes zoster could be an early manifestation of undiagnosed human immunodeficiency virus infection. J Formos Med Assoc 115: 372-376. [Crossref]

6. Grabar S, Tattevin P, Selinger-Leneman H, de La Blanchardiere A, de Truchis P, et al (2015) Incidence of herpes zoster in HIV-infected adults in the combined antiretroviral therapy era: results from the FHDH-ANRS CO4 cohort. Clin Infect Dis 60: 1269-1277. [Crossref]

7. Jansen K, Haastert B, Michalik C, Guignard A, Esser S, et al. (2013) Incidence and risk factors of herpes zoster among hiv-positive patients in the german competence network for HIV/AIDS (KompNet): a cohort study analysis. BMC Infect Dis 13: 372. [Crossref]

8. Johnson R, McElhaney J, Pedalino B, Levin M (2007) Prevention of herpes zoster and its painful and debilitating complications. Int $J$ Infect Dis 11 Suppl 2: S43-48. [Crossref]

9. Thomas SL, Hall AJ (2004) What does epidemiology tell us about risk factors for herpes zoster? Lancet Infect Dis 4: 26-33. [Crossref]

10. Gebo KA, Kalyani R, Moore RD, Polydefkis MJ (2005) The incidence of, risk factors for, and sequelae of herpes zoster among HIV patients in the highly active antiretroviral therapy era. J Acquir Immune Defic Syndr 40: 169-174. [Crossref]

11. US. Preventive Services Task Force. Screening for HIV. Available at http://www. uspreventiveservicestaskforce.org/uspstf/uspshivi.htm. Accessed: June 16, 2011.

12. Branson BM, Handsfield HH, Lampe MA, Janssen RS, Taylor AW, et al. (2006) Revised recommendations for HIV testing of adults, adolescents, and pregnant women in health-care settings. MMWR Recomm Rep 55: 1-17. [Crossref]

13. Qaseem A, Snow V, Shekelle P, Hopkins R Jr, Owens DK, et al. (2009) Screening for HIV in health care settings: a guidance statement from the American College of Physicians and HIV Medicine Association. Ann Intern Med 150: 125-131. [Crossref]

14. Panel on Antiretroviral Guidelines for Adults and Adolescents (2011) Guidelines for the use of antiretroviral agents in HIV-1-infected adults and adolescents. Department of Health and Human Services: 1-174.

15. Lowes R (2013) FDA OKs First Rapid Test for HIV-1/2 Antibodies, HIV-1 Antigen. Medscape Accessed: August 15, 2013.

16. [No authors listed] (1992) 1993 revised classification system for HIV infection and expanded surveillance case definition for AIDS among adolescents and adults. MMWR Recomm Rep 41: 1-19. [Crossref]

17. Mellors JW, Muñoz A, Giorgi JV, Margolick JB, Tassoni CJ, et al. (1997) Plasma viral load and CD4+ lymphocytes as prognostic markers of HIV-1 infection. Ann Intern Med 126: 946-954. [Crossref]

18. Rodríguez B, Sethi AK, Cheruvu VK, Mackay W, Bosch RJ, et al. (2006) Predictive value of plasma HIV RNA level on rate of CD4 T-cell decline in untreated HIV infection. JAMA 296: 1498-1506. [Crossref]

19. Pantaleo G, Graziosi C, Fauci AS (1993) New concepts in the immunopathogenesis of human immunodeficiency virus infection. $N$ Engl J Med 328: 327-335. [Crossref]

20. Pantaleo G, Fauci AS (1995) New concepts in the immunopathogenesis of HIV infection. Annu Rev Immunol 13: 487-512. [Crossref]

21. Weber J (2001) The pathogenesis of HIV-1 infection. Br Med Bull 58: 61-72. [Crossref]

22. Poles MA, Boscardin WJ, Elliott J, Taing P, Fuerst MM, et al. (2006) Lack of decay of HIV-1 in gut-associated lymphoid tissue reservoirs in maximally suppressed individuals. J Acquir Immune Defic Syndr 43: 65-68. [Crossref]

23. Hellerstein M, Hanley MB, Cesar D, Siler S, Papageorgopoulos C, et al. (1999) Directly measured kinetics of circulating $\mathrm{T}$ lymphocytes in normal and HIV-1-infected humans. Nat Med 5: 83-89. [Crossref]

24. Mohri H, Perelson AS, Tung K, Ribeiro RM, Ramratnam B, et al. (2001) Increased turnover of T lymphocytes in HIV-1 infection and its reduction by antiretroviral therapy. J Exp Med 194: 1277-1287. [Crossref] 
25. Bird JJ, Brown DR, Mullen AC, Moskowitz NH, Mahowald MA, et al. (1998) Helper $\mathrm{T}$ cell differentiation is controlled by the cell cycle. Immunity 9: 229-237. [Crossref]

26. Lederman MM (2001) Immune restoration and CD4+ T-cell function with antiretroviral therapies. AIDS 15 Suppl 2: S11-15. [Crossref]

27. van der Ende ME, Schutten M, Raschdorff B, Grossschupff G, Racz P, et al. (1999) CD4 T cells remain the major source of HIV-1 during end stage disease. AIDS 13: 1015-1019. [Crossref]

28. McCune JM (2001) The dynamics of CD4+ T-cell depletion in HIV disease. Nature 410: 974-979. [Crossref]

29. Pantaleo G, Graziosi C, Demarest JF, Butini L, Montroni M, et al. (1993) HIV infection is active and progressive in lymphoid tissue during the clinically latent stage of disease. Nature 362: 355-358. [Crossref]

30. Edén A, Fuchs D, Hagberg L, Nilsson S, Spudich S, et al. (2010) HIV-1 viral escape in cerebrospinal fluid of subjects on suppressive antiretroviral treatment. J Infect Dis 202: 1819-1825. [Crossref]

31. Schröder AR, Shinn P, Chen H, Berry C, Ecker JR, et al. (2002) HIV-1 integration in the human genome favors active genes and local hotspots. Cell 110: 521-529. [Crossref]

32. Blankson JN, Persaud D, Siliciano RF (2002) The challenge of viral reservoirs in HIV-1 infection. Annu Rev Med 53: 557-593. [Crossref]

33. Chun TW, Engel D, Berrey MM, Shea T, Corey L, et al. (1998) Early establishment of a pool of latently infected, resting CD4(+) T cells during primary HIV-1 infection. Proc Natl Acad Sci U S A 95: 8869-8873. [Crossref]

34. Ho DD, Moudgil T, Alam M (1989) Quantitation of human immunodeficiency virus type 1 in the blood of infected persons. N Engl J Med 321: 1621-1625. [Crossref]

35. Zoufaly A, an der Heiden M, Kollan C, Bogner JR, Fätkenheuer G, et al. (2011) Clinical outcome of HIV-infected patients with discordant virological and immunological response to antiretroviral therapy. J Infect Dis 203: 364-371. [Crossref]

36. Mills EJ, Bakanda C, Birungi J, Yaya S, Ford N; TASO-CAN Writing Group (2012) The prognostic value of baseline CD4(+) cell count beyond 6 months of antiretrovira therapy in HIV-positive patients in a resource-limited setting. AIDS 26: 1425-1429. [Crossref]

37. Tao G, Hoover KW, Leichliter JS, Peterman TA, Kent CK (2012) Self-reported Chlamydia testing rates of sexually active women aged 15-25 years in the United States, 2006-2008. Sex Transm Dis 39: 605-607. [Crossref]

38. Centers for Disease Control and Prevention (CDC) (2010) Prevalence and awareness of HIV infection among men who have sex with men --- 21 cities, United States, 2008. MMWR Morb Mortal Wkly Rep 59: 1201-1207.

39. Centers for Disease Control and Prevention (CDC) (2012) Vital signs: HIV infection, testing, and risk behaviors among youths - United States. MMWR Morb Mortal Wkly Rep 61: 971-976. [Crossref]

40. Levy JA (1993) HIV pathogenesis and long-term survival. AIDS 7: 1401-1410 [Crossref]

41. CDC (2014) Laboratory Testing for the Diagnosis of HIV Infection: Updated Recommendations. Centers for Disease Control and Prevention. 2014.

42. Bucy RP, Hockett RD, Derdeyn CA, Saag MS, Squires K, et al. (1999) Initial increase in blood CD4(+) lymphocytes after HIV antiretroviral therapy reflects redistribution from lymphoid tissues. J Clin Invest 103: 1391-1398. [Crossref]

43. Aberg JA, Gallant JE, Ghanem KG, Emmanuel P, Zingman BS, et al. (2013) Primary Care Guidelines for the Management of Persons Infected With HIV: 2013 Update by the HIV Medicine Association of the Infectious Diseases Society of America. Clin Infect Dis.

44. World Health Organization (2013) Consolidated Guidelines on the Use of Antiretroviral Drugs for Treating and Preventing HIV Infection. Jun 2013.

45. EACS (2013) European AIDS Clinical Society Guidelines, version 7.0. Oct 2013

46. When To Start Consortium, Sterne JA, May M, Costagliola D, de Wolf F, et al. (2009) Timing of initiation of antiretroviral therapy in AIDS-free HIV-1-infected patients: collaborative analysis of $18 \mathrm{HIV}$ cohort studies. Lancet 373: 1352-1363. [Crossref]

47. HIV-CAUSAL Collaboration, Cain LE, Logan R, Robins JM, Sterne JA, et al. (2011) When to initiate combined antiretroviral therapy to reduce mortality and AIDS-defining illness in HIV-infected persons in developed countries: an observational study. Ann Intern Med 154: 509-515. [Crossref]

48. Günthard HF, Aberg JA, Eron JJ, Hoy JF, Telenti A, et al. (2014) Antiretroviral treatment of adult HIV infection: 2014 recommendations of the International Antiviral Society-USA Panel. JAMA 312: 410-425. [Crossref]

49. Havlir DV, Bassett R, Levitan D, Gilbert P, Tebas P, et al. (2001) Prevalence and predictive value of intermittent viremia with combination hiv therapy. JAMA 286: 171179. [Crossref]

50. Ragozzino MW, Melton LJ 3rd, Kurland LT, Chu CP, Perry HO (1982) Populationbased study of herpes zoster and its sequelae. Medicine (Baltimore) 61: 310-316. [Crossref]

51. Donahue JG, Choo PW, Manson JE, Platt R (1995) The incidence of herpes zoster. Arch Intern Med 155: 1605-1609. [Crossref]

52. Hope-Simpson RE (1965) The Nature of Herpes Zoster: A long-term study and a new hypothesis. Proc R Soc Med 58: 9-20. [Crossref]

53. Buchbinder SP, Katz MH, Hessol NA, Liu JY, O'Malley PM, et al. (1992) Herpes zoster and human immunodeficiency virus infection. J Infect Dis 166: 1153-1156. [Crossref]

54. Glesby MJ, Moore RD, Chaisson RE (1995) Clinical spectrum of herpes zoster in adults infected with human immunodeficiency virus. Clin Infect Dis 21: 370-375. [Crossref]

55. Veenstra J, Krol A, van Praag RM, Frissen PH, Schellekens PT, et al. (1995) Herpes zoster, immunological deterioration and disease progression in HIV-1 infection. AIDS 9: 1153-1158. [Crossref]

56. McNulty A, Li Y, Radtke U, Kaldor J, Rohrsheim R, et al. (1997) Herpes zoster and the stage and prognosis of HIV-1 infection. Genitourin Med 73: 467-470. [Crossref]

57. Feller L, Wood NH, Lemmer J (2007) Herpes zoster infection as an immune reconstitution inflammatory syndrome in HIV-seropositive subjects: a review. Oral Surg Oral Med Oral Pathol Oral Radiol Endod 104: 455-460. [Crossref]

58. Melbye M, Grossman RJ, Goedert JJ, Eyster ME, Biggar RJ (1987) Risk of AIDS after herpes zoster. Lancet 1: 728-731. [Crossref]

59. AIDS INFO 2014:Laboratory Testing Plasma HIV-1 RNA (Viral Load) and CD4 Count Monitoring

60. Brambilla AM1, Castagna A, Nocita B, Hasson H, Boeri E, et al. (2001) Relation between CD4 cell counts and HIV RNA levels at onset of opportunistic infections. $J$ Acquir Immune Defic Syndr 27: 44-48. [Crossref]

61. [Crossref] Bour S1, Geleziunas R, Wainberg MA (1995) The human immunodeficiency virus type 1 (HIV-1) CD4 receptor and its central role in promotion of HIV-1 infection. Microbiol Rev 59: 63-93.

62. www.surgicalnotes.co.uk

63. Veenstra J, van Praag RM, Krol A, Wertheim van Dillen PM, Weigel HM, et al. (1996) Complications of varicella zoster virus reactivation in HIV-infected homosexual men. AIDS 10: 393-399. [Crossref]

64. Buchbinder SP, Katz MH, Hessol NA, Liu JY, O'Malley PM, et al. (1992) Herpes zoste and human immunodeficiency virus infection. $J$ Infect Dis 166: 1153-1156. [Crossref]

65. Lidhoo P, Unemori P, Leslie KS, Maurer T (2009) Disseminated herpes zoster with increased CD4 counts in 3 HIV-infected patients. J Am Acad Dermatol 61: 345-347. [Crossref]

66. Kaplan JE, Hanson DL, Jones JL, Dworkin MS; Adult and Adolescent Spectrum of HIV Disease Project Investigators (2001) Viral load as an independent risk factor for opportunistic infections in HIV-infected adults and adolescents. AIDS 15: 1831-1836. [Crossref]

67. Rondaan C, de Haan A, Horst G, Hempel JC, van Leer C, et al. (2014) Altered cellula and humoral immunity to varicella-zoster virus in patients with autoimmune diseases. Arthritis Rheumatol 66: 3122-3128. [Crossref]

68. Gebo KA, Kalyani R, Moore RD, Polydefkis MJ (2005) The incidence of, risk factors for, and sequelae of herpes zoster among HIV patients in the highly active antiretroviral therapy era. J Acquir Immune Defic Syndr 40: 169-174. [Crossref]

Copyright: (C2016 Prokopia V. This is an open-access article distributed under the terms of the Creative Commons Attribution License, which permits unrestricted use, distribution, and reproduction in any medium, provided the original author and source are credited. 